\title{
Business skills development for a successful fashion business in peri-urban communities, South Africa
}

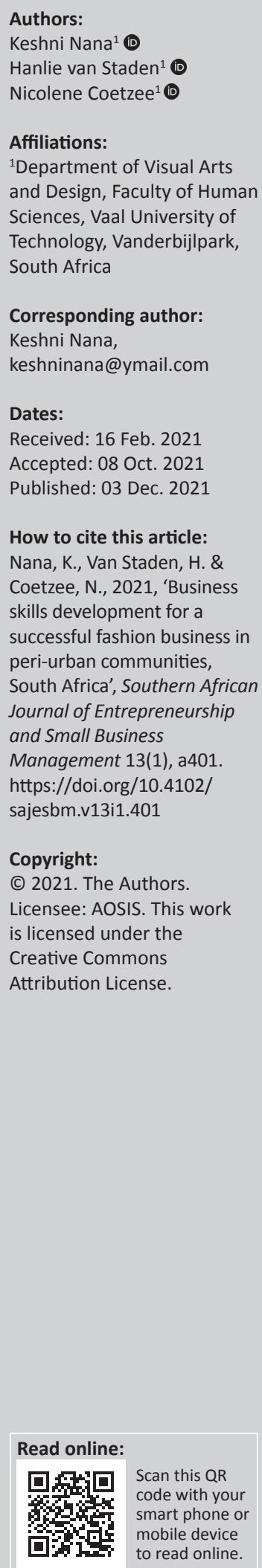

Background: Entrepreneurs from disadvantaged backgrounds often possess low levels of education, limited qualifications and training. This also applies to survivalist fashion entrepreneurs in the Sedibeng District Municipality (SDM), Gauteng. Over a third of these entrepreneurs are not formally educated in business skills and may not possess the adequate knowledge to operate their fashion business successfully.

Aim: The aim of this research was to investigate the uses and challenges pertaining to business skills amongst fashion entrepreneurs without formal, fashion-related education or training, in order to determine their business skills' training needs.

Setting: The sample population included 105 black, adult fashion entrepreneurs, operating micro, survivalist fashion enterprises within peri-urban, resource-poor communities in the Emfuleni Local Municipality (ELM) of the Sedibeng district. Data for this study were collected from the respondents whilst shopping at fabric and haberdashery stores or from their homebusiness environments.

Methods: A quantitative study applying non-probability, purposive and snowball sampling was performed. Data were collected by means of interviewer-administered questionnaires by trained fieldworkers.

Results: The results indicated that the respondents lacked skills in developing business plans and possessed only moderate skills in finance and marketing. The respondents indicated training needs for fashion business skills in all areas of investigation, including developing a business plan, conducting basic bookkeeping, determining correct product pricing, drafting quotations and invoices, developing a budget, conducting basic market research and advertising their products and services.

Conclusion: Fashion business skill training programmes should be developed to target and train fashion entrepreneurs without formal fashion-related education or training, contributing to the long-term sustainability of local fashion businesses in South Africa (SA).

Keywords: fashion business skills; peri-urban communities; resource-poor; survivalist enterprise; training needs.

\section{Introduction}

The majority of small, medium and micro enterprises (SMMEs) operating in SA comprise unregistered, informal, survivalist businesses, inferring that it only makes a minor contribution to the overall economic growth, with neither a significant improvement to the standard of living nor the creation of job opportunities, to overcome unemployment (Department of Trade and Industry 2008; eds. Erasmus, Strydom \& Rudansky-Kloppers 2013; Rogerson 2006:69; Small Enterprise Development Agency 2019). The ability of individuals to positively contribute to job creation requires a basic education, business skills, industry experience and finances (Moloi \& Nkhahle 2014:225).

Because of a lack of skills, previously disadvantaged adults have low chances of finding employment and therefore remain unemployed (Mavunga \& Cross 2017:304; Mayombe 2017:149). South Africa's greatest limitation in overcoming unemployment is a shortage of local entrepreneurs, which can be resolved through education and training for operating a business (Lewis \& Gasealahwe 2017:6). Considering this, one of the challenges faced by SA is the development and improvement of business knowledge and skills. Along with an alarmingly high $32.6 \%$ unemployment rate (Statistics South Africa (Stats SA) 2021:1), the predominant causes for general business failure amongst SMMEs in SA include a lack of business skills and training, poor 
education, cultural and family backgrounds and poverty (Malgas \& Zondi 2020:8; Moloi \& Nkhahle 2014:226; Rogerson 2008:71; Rwigema \& Venter 2007). This is experienced especially amongst the previously disadvantaged and marginalised groups of the population (i.e. the older black South African population who may have low levels of education) residing outside of the more advanced suburbs (Moloi \& Nkhahle 2014:226). These individuals operate informal businesses that often struggle to succeed (Rwigema \& Venter 2007).

It is important for fashion entrepreneurs to possess relevant business knowledge, financial skills, marketing skills, as well as fashion-related skills (such as designing, pattern drafting and garment construction), in order to operate profitable, sustainable fashion enterprises (Fernandes 2019:8; Groenewald 2001; Ladzani \& Van Vuuren 2002:155). Details within this article are derived from a larger study that investigated business skills amongst fashion entrepreneurs without formal fashion-related education or training, within the Emfuleni Local Municipality (ELM). The purpose of this article, however, is to explore these fashion entrepreneurs' own perception of their business skills, in order to make recommendations for business skills training. These business skills are explored in terms of current use of business skills, challenges related to business skills and the need for training in business skills, specifically focused on business plan development skills, financial skills and marketing skills.

The following section of this article provides a literature review that discusses the state of SMME operation in SA, the challenges imposed on SA's entrepreneurial performance, and previous research findings that necessitate business skills development for SA by highlighting current practices amongst fashion businesses within the country. The literature review is followed by the research methods and design of this study, its results, discussion and conclusion.

\section{Literature review}

\section{The state of small, medium and micro enterprise operation in South Africa}

Successful SMMEs are known to positively contribute to the country's Gross Domestic Product by promoting entrepreneurship, allowing entrepreneurs to operate competitively, grow exportation, reduce poverty and create employment (Coleman 2000:37; Department of Trade and Industry (DTI) 2008:xxvii, Ramukumba 2014:20; Rogerson 2006:66). The growth of SA's SMME economy is mostly because of unemployment and the search for alternative or new forms of income amongst individuals (Rogerson 2006:69). Rather than pursuing sighted business opportunities, labour market entrants who are unable to find work within the formal sector, resort to establishing unregistered, informal, survivalist businesses as a source of household income and an escape from unemployment (Isaacs et al. 2007:616; Ligthelm 2008:371; Ramukumba 2014:21).
South Africa's SMME economy has been described as stagnant, being far from generating the wealth and employment that SA needs and less dynamic because of businesses dissolving at very early stages (i.e. less than three and a half years in existence) (DTI 2008:xxvii; Ramukumba 2014:32). It is reported that micro and small businesses are not expanding for two reasons: (1) employing low-skilled staff or (2) being unable to assist in employment creation because of numerous challenges, resulting in ultimate failure (Ligthelm 2008:367; Ramukumba 2014:20). There is also a high rate of liquidation, large numbers of registered but inactive businesses and the shifting of business focus within the early stages of existence, concluding that successful business operation in SA is less than average (DTI 2008:xxvii). This may be ascribed to several challenges faced by emerging South African SMMEs, namely a lack of adequate finance, limited market access, crime, repercussions of labour laws, repercussions of being previously disadvantaged, and a lack of adequate education and training.

\section{Challenges imposed on South Africa's entrepreneurial performance}

Statistics indicate that more than half of SA population who are unemployed have not completed Grade 12 (Stats SA 2020:13). Poor education and training have resulted in low productivity, which has led to minor specialisation within the entrepreneurial field (eds. Erasmus et al. 2013:596). The skills shortage experienced amongst SAs inadequately educated workforce proves to be a constraint in small business development (Bureau for Economic Research (BER) 2016:9). It is known that a problem with productivity exists within SA as there is a shortage of skilled labour (i.e. properly trained business owners) (BER 2016:5; eds. Erasmus et al. 2013:596). The lack of skills and entrepreneurship capacity are hindrances to employment growth within the country and are observed amongst South Africans who struggle to initiate and successfully operate their own businesses (BER 2016:9; Breward 2010:357; Ramukumba 2014:20).

Entrepreneurial performance is measured against two prominent categories, namely entrepreneurial skills and business skills (Ladzani \& Van Vuuren 2002:155), which, in the instance of this study, applies to fashion entrepreneurs. Business skills constitute business plan development skills, financial skills, marketing skills, leadership skills and human resource skills, which are crucial within the fashion industry (Kamara 2014:121; Ladzani \& Van Vuuren 2002:157) for fashion entrepreneurs to operate successful and sustainable fashion ventures. The specific aspects associated within fashion entrepreneurial skills include the fashion entrepreneur's ability to identify opportunities, their level of creativity and innovation and their ability to take risks (Burke 2010:30). For the purpose of this article, the focus is on the fashion entrepreneurs' own perception of their business skills.

\section{A call for business skills development in South Africa}

Previous research indicated that SMMEs within their start-up phases reflected a lack of knowledge within the particular 
business being operated (Rogerson 2006:71). From a study conducted by Naidoo in the Sedibeng District Municipality (SDM), over a quarter of fashion entrepreneurs felt that they did not have adequate levels of business knowledge (2009:130). Poor business knowledge and a lack of networks affect the performance of SA's SMMEs (Ramukumba 2014:25; Rogerson 2000:696, 2006:73).

Entrepreneurs within resource-poor areas have been found to lack the basic financial and accounting skills required to manage various costs in the business (Viswanathan, Sridharan \& Ritchie 2009:571). Unqualified fashion entrepreneurs may also not have access to, or the skills required, to perform bookkeeping with the assistance of a computer or afford to employ the services of a private bookkeeper. Seeking advice from neighbours and surrounding locals are, therefore, common practices of business owners in resource-poor areas (Viswanathan et al. 2009:571). Clients within resource-poor communities may also not be able to pay for their products upon completion and may expect the fashion entrepreneur to accommodate their needs, resulting in unstable pricing structures for the fashion business (Viswanathan et al. 2009:571).

Businesses situated within resource-poor areas are regarded as network rich because of the social relations amongst members of the community who assist in the transfer of information and the development of consumer and entrepreneurial skills (Viswanathan et al. 2009:570). Naidoo (2009:138) found that word-of-mouth promotion was predominantly used by fashion entrepreneurs in the SDM to market their business. Should customers be satisfied with the quality of the business' products and services, they will provide word-of-mouth recommendations to their family and friends (Ramukumba 2014:33). However, should the business be communicated negatively, it could hinder the survival of the business.

As such, starting a fashion business requires education in business studies, amongst others, such as business management, entrepreneurship, human resources and retail merchandising (Vaal University of Technology 2020). The acquisition of this knowledge generally forms part of the academic curriculum of accredited fashion courses. Mayombe (2017:150), however, refers to non-formal education and training as equipping adults of resource-poor communities with skills required for earning an income through selfemployment and the operation of a micro enterprise. It has been suggested that the provision for formal business skills education and training be made for fashion entrepreneurs in the SDM, through short entrepreneurial courses (namely business management, business plan development, bookkeeping and marketing) (Naidoo 2009; Van Wyk \& Van Aardt 2011:182).

Because of the high unemployment rate in resource-poor areas and many small business owners having medium to low forms of formal education (Isaacs et al. 2007:626; Kugler et al. 2017:44; Redmond \& Walker 2008:698), there is a need to develop strategies for sustaining businesses and ultimately improving economic growth (Nheta et al. 2020:5). This is the reason why training directed towards fashion entrepreneurial performance is regarded as highly beneficial (Nieuwenhuizen 2008:2).

In conclusion to the literature review, Figure 1 depicts the conceptual framework used for the empirical research of this study. This article explores fashion entrepreneurs without formal fashion-related education or training's demographic characteristics, background of their fashion business, current use of business skills, challenges related to business skills, and the need for training in business skills, as reported by respondents, in order to make recommendations for business skills training.

\section{Research methods and design Study design}

The study was grounded within the post-positivist approach as it involved empirical observation and measurement, deterministic philosophy and reductionist intent (Creswell 2014:6). The study employed a quantitative research methodology and a non-experimental, cross-sectional, exploratory survey design to achieve the aim of the study. A needs assessment was performed as business skills training needs of fashion entrepreneurs without fashion-related education or training were investigated, whereby respondents may benefit in the future. In order to fulfil the aim of the study, specific objectives sought to investigate the extent for business skills training, in terms of:

- demographic characteristics of respondents in order to identify the majority of fashion entrepreneurs who lack business skills to successfully operate their fashion businesses

- background of the fashion business

- current use of business skills amongst respondents

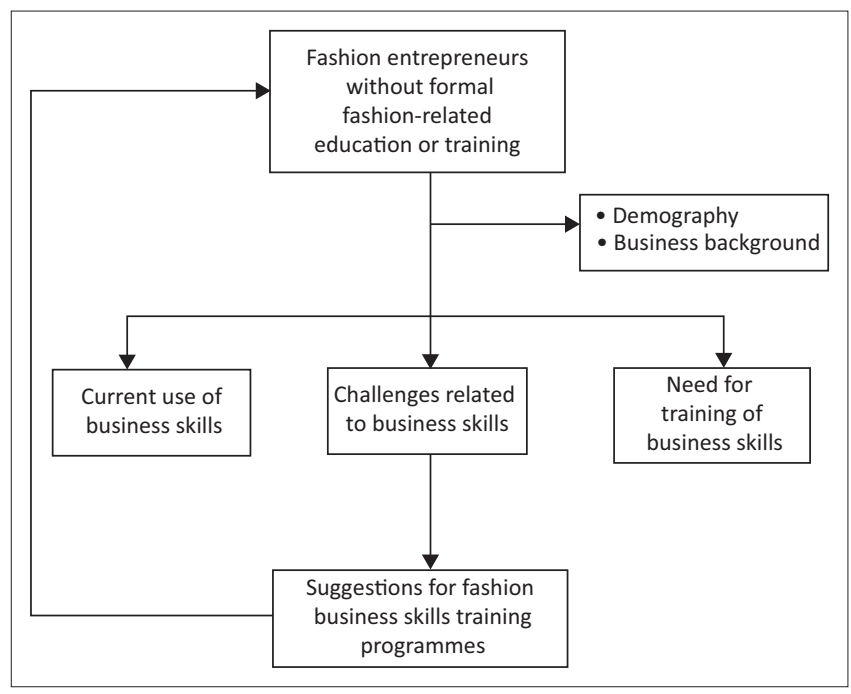

FIGURE 1: Conceptual framework. 
- challenges related to business skills experienced by respondents, and

- need for training of business skills amongst respondents to overcome their shortfalls.

As this study was largely explorative, the findings will contribute to the existing literature and to future research by informing the content on which training programmes directed at fashion business skills should be based.

\section{Setting}

The setting of this study was the SDM, which is situated approximately 75 kilometers from Johannesburg (Google Maps 2020) and has an estimated population of more than 1 million people and three local municipalities, namely Emfuleni, Lesedi and Midvaal (Department of Cooperative Governance \& Traditional Affairs 2020). Emfuleni has the largest population $(77 \%)$, with the largest unemployment rate (56.2\%) (Gauteng Provincial Treasury 2019). The focus of this study was on black fashion entrepreneurs without formal fashion-related education or training situated within the ELM's peri-urban, resource-poor communities.

Data collection for this study took place within fabric and haberdashery stores located in Vereeniging and Vanderbijlpark within the ELM, popularly known for the selling of fabrics, haberdashery and miscellaneous items. The option was provided to the respondents for the completion of the questionnaires in their home-business environment (as the fashion entrepreneurs' business may very likely be operational from their homes) (Kugler et al. 2017:44; Martins 2005).

\section{Study population and sampling strategy}

The study population comprised of fashion entrepreneurs without formal fashion-related education or training who are owners of fashion businesses, in particular micro, survivalist enterprises. The following inclusion criteria were applied for the respondents to be able to participate in the study:

- fashion entrepreneurial adults (18 years and older, to be able to give consent to partake in the study)

- no post-school fashion qualification or training

- operating micro or survivalist fashion businesses, which employ 1-5 employees

- operating for a minimum of 2 years or more

- located within a resource-poor, peri-urban community in the Emfuleni region of the SDM.

Whilst the total population of fashion entrepreneurs within the ELM is unknown, a total of 140 fashion entrepreneurs were identified in a study conducted by Van Wyk in 2007. A sample range of between 100 and 120 respondents was suggested to be adequate by the consulting Statistical Consultation Services at the North-West University, as the findings and results generated from a non-probability sampling method cannot be generalised to the entire population (Nardi 2006). Purposive and snowball sampling was used for contacting the respondents within this study, which are considered as common forms of non-probability sampling methods found within quantitative research (Babbie 2010:192; Gorard 2013:84). Non-probability purposive sampling involved the selection of with whom, where and how the research was to be conducted, in relation to the study's objectives (Palys 2008:697). Snowball sampling was used as a further means of identifying respondents as it was assumed that members of the sample population share similar characteristics and therefore able to identify others who share their similar attributes, thus allowing the study to operate on the basis of referrals (Daniel 2012:109; Nardi 2006:120).

The measuring instrument administered consisted of an interviewer-administered questionnaire because of the better quality of data achieved, as the administer could clarify items on the questionnaire, resulting in a greater quantity of data and higher response rates (Martins 2005). Questionnaires from three different research studies were consulted to assist in compiling the questionnaire for this investigation, including Van Wyk (2007), Kunene (2008) and Naidoo (2009). Content within these questionnaires closely related to sections within this study in terms of fashion business owners and the Sedibeng district. Following Van Wyk (2007) and Naidoo's (2009) focus on fashion businesses within the Sedibeng district and Kunene's (2008) study featuring business owners within the textile and clothing industry in Gauteng, several questions were adapted to suit the purpose of this study. The questionnaire was developed at a grade level of Grade 6 and below (as measured by the FleschKincaid readability grade-level indicator) as only $28.6 \%$ of ELM's population achieved a Matriculation pass (Gauteng Provincial Treasury 2019). The questionnaire was therefore developed to better suit respondent's comprehension and to avoid intimidating respondents if they were unsure as to what a construct was referring to. As Sesotho is the most widely spoken language amongst black individuals in the SDM (Hunter 2016), accredited language translators translated the study's consent form and questionnaire into Sesotho. Once translated, the consent form and questionnaire were back translated by a Sesotho speaking person to ensure accuracy during translation.

\section{Data collection}

Data were collected from a total of 105 respondents over a period of 6 weeks. Prior to data collection, a letter requesting permission from the fabric and haberdashery store owners and managers was sent, to use their store as the location to meet respondents for this study.

Considering the characteristics of the sample population of this study (possible low literacy levels and language barriers) and the actual data collection requiring more than one administer (Babbie \& Mouton 2016), four Sesotho speaking fieldworkers were employed. These fieldworkers were trained to assist with the data collection from respondents to complete the questionnaire process. Considering the low 
levels of literacy amongst adult South Africans (Aitchison 2015:134; Posel 2011:39), the completion of the questionnaire was done on a one-on-one basis, in order to reduce the possibility of anxiety or embarrassment if a respondent had reading or writing difficulties (Viswanathan, Gau \& Chaturvedi 2008) and to achieve a higher response rate (Babbie 2013; Babbie \& Mouton 2016).

\section{Validity and reliability}

Face validity was applied whereby the statistician and study leaders scrutinised the questionnaire before it was administered (Maree 2007). A pilot test was conducted with respondents known to display the similar characteristics as the actual sample group, thus ensuring that the questionnaire measured what it had intended to measure. Construct validity was assessed through statistical procedures. Exploratory factor analysis was applied to ordinal-scaled questions where many options were provided.

Cronbach's alpha was used to measure internal consistency for questions with multiple-scored items. Therefore, the closer the alpha co-efficient was to 1.0, the more reliable the questionnaire was (Malhotra 2010; Nardi 2006). An additional measure, which increased the reliability of the collected data, was through the interviewer-administered questionnaire conducted by trained fieldworkers (Babbie 2013; Babbie \& Mouton 2016; Malhotra 2015; Oishi 2003). The researcher took care in the proper training of the fieldworkers, and each questionnaire was scrutinised before data analysis for discrepancies, persistent responses or patterns.

\section{Ethical considerations}

Ethical clearance was obtained from the Vaal University of Technology's Ethics Committee in order to conduct the research (permit number: ECN09-2016). Ethical standards were maintained whereby responses were recorded with no misrepresentation or deception, informed consent was obtained from respondents and the researcher took all possible measures to ensure confidentiality of information and results. This confidentiality was further extended to all parties handling the data, including the fieldworkers and the translators of the data collection instruments, who signed confidentiality agreements. The researcher, study leaders and the statistician for the study were the only individuals who had access to the data, thereby minimising undue risks.

\section{Data analysis}

Every completed questionnaire was examined and coded in order to verify the usability of the questionnaires. Data were then analysed using the Statistical Package for the Social Sciences programme (IBM SPSS Version 23). Analyses performed included descriptive analysis that summarised and presented the responses in manageable forms for every section of the questionnaire through statistical computations, which described the characteristics or relationships amongst variables in the sample (Babbie 2010). As factors derived from larger samples generalise better than from smaller sample populations (Pallant 2010), the results of this study serve merely as an indication rather than a generalisation of the population.

\section{Results}

Aligning to the objectives of the study, the results were extracted and are presented below.

Table 1 presents the demographic characteristics of the respondents. This provides vital data to identify the majority of fashion entrepreneurs without formal, fashionrelated education or training within peri-urban communities who lack business skills to successfully operate their fashion businesses. The presented results may aid the development and focus of future fashion business skills training programmes.

It is evident that the majority of respondents were female $(84.5 \%)$ who belonged to the older age group (between 50 and 59 years old with 32.7\%). More than half of the respondents were married (52.9\%), and Grade 12 was reported to be the highest level of education achieved for $46.5 \%$ of respondents. The majority of respondents $(73.8 \%)$ had operated their business for 5 years or more.

It may therefore be interpreted that most of the fashion entrepreneurs without formal fashion-related education or

TABLE 1: Demographic characteristics of respondents.

\begin{tabular}{|c|c|c|c|c|}
\hline Question number & Demographic characteristics & $N$ & $n$ & $(\%)$ \\
\hline A.1 & Gender & 103 & - & - \\
\hline A.1.1 & Female & - & 87 & 84.5 \\
\hline A.1.2 & Male & - & 16 & 15.5 \\
\hline A.2 & Age (years) & 104 & - & - \\
\hline A.2.1 & $18-29$ & - & 9 & 8.7 \\
\hline A.2.2 & $30-39$ & - & 25 & 24.0 \\
\hline A.2.3 & $40-49$ & - & 23 & 22.1 \\
\hline A.2.4 & $50-59$ & - & 34 & 32.7 \\
\hline A. 2.5 & 60 years and older & - & 13 & 12.5 \\
\hline A.3 & Marital status & 104 & - & - \\
\hline A.3.1 & Never married & - & 31 & 29.8 \\
\hline A.3.2 & Married & - & 55 & 52.9 \\
\hline A.3.3 & Cohabitation/living together & - & 1 & 1.0 \\
\hline A.3.4 & Divorced/separated & - & 7 & 6.7 \\
\hline A.3.5 & Widowed & - & 10 & 9.6 \\
\hline A.4 & Highest level of education & 99 & - & - \\
\hline A.4.1 & Grade $1-5 /$ Sub A-Standard 3 & - & 5 & 5.1 \\
\hline A.4.2 & Grade 6/Standard 4 & - & 3 & 3.0 \\
\hline A.4.3 & Grade $7 /$ Standard 5 & - & 5 & 5.1 \\
\hline A.4.4 & Grade $8 /$ Standard 6 & - & 4 & 4.0 \\
\hline A.4.5 & Grade $9 /$ Standard 7 & - & 4 & 4.0 \\
\hline A.4.6 & Grade $10 /$ Standard 8 & - & 11 & 11.1 \\
\hline A.4.7 & Grade $11 /$ Standard 9 & - & 21 & 21.2 \\
\hline A.4.8 & Grade $12 /$ Standard 10 & - & 46 & 46.5 \\
\hline A.5 & Duration of business & 103 & - & - \\
\hline A.5.1 & 2 years & - & 15 & 14.6 \\
\hline A.5.2 & 3 years & - & 6 & 5.8 \\
\hline A.5.3 & 4 years & - & 6 & 5.8 \\
\hline A.5.4 & 5 years and more & - & 76 & 73.8 \\
\hline
\end{tabular}


TABLE 2: Factors and questionnaire items.

\begin{tabular}{|c|c|c|c|}
\hline $\begin{array}{l}\text { Question extracted from } \\
\text { questionnaire }\end{array}$ & Items & Name of factor & $\begin{array}{l}\text { Cronbach } \\
\text { alpha } \\
\text { coefficient }\end{array}$ \\
\hline \multirow[t]{3}{*}{$\begin{array}{l}\text { 1. How much did the } \\
\text { following factors } \\
\text { motivate you to start } \\
\text { your own business: }\end{array}$} & $\begin{array}{l}\text { - Spouse } \\
\text { - Friends } \\
\text { - Role models } \\
\text { - Parents and/or } \\
\text { other family } \\
\text { members } \\
\text { - Religious leader }\end{array}$ & People & 0.81 \\
\hline & $\begin{array}{l}\text { - Subjects studied } \\
\text { at school } \\
\text { - Teachers at } \\
\text { school }\end{array}$ & Education & 0.71 \\
\hline & $\begin{array}{l}\text { - Could not find a } \\
\text { job } \\
\text { - Earned more } \\
\text { money than } \\
\text { working for } \\
\text { someone else } \\
\text { - Previous work } \\
\text { experience } \\
\text { - Parents who } \\
\text { have/had their } \\
\text { own business }\end{array}$ & $\begin{array}{l}\text { Employment } \\
\text { experience }\end{array}$ & 0.60 \\
\hline \multirow[t]{2}{*}{$\begin{array}{l}\text { 2. In terms of the problems } \\
\text { you experience with } \\
\text { business skills, how well } \\
\text { would you say you: }\end{array}$} & $\begin{array}{l}\text { - Do cost } \\
\text { calculations? } \\
\text { - Keep a record of } \\
\text { the money in } \\
\text { your business? } \\
\text { - Draw up a } \\
\text { budget? } \\
\text { - Advertise your } \\
\text { products and/or } \\
\text { services? } \\
\text { - Find out what } \\
\text { customers want? }\end{array}$ & $\begin{array}{l}\text { Financial and } \\
\text { marketing skills }\end{array}$ & 0.84 \\
\hline & $\begin{array}{l}\text { - Understand the } \\
\text { use of a business } \\
\text { plan? } \\
\text { - Understand what } \\
\text { a business plan } \\
\text { is? } \\
\text { Draw up a } \\
\text { business plan? }\end{array}$ & $\begin{array}{l}\text { Business plan } \\
\text { development } \\
\text { skills }\end{array}$ & 0.84 \\
\hline
\end{tabular}

training in the ELM are middle aged (30-59 years old), married females, who have obtained a Grade 12 qualification. Similarly, previous research conducted amongst female fashion entrepreneurs in the SDM, indicated that the majority of respondents were married (Naidoo 2009:129). It may be said that these entrepreneurs have been operating their business for a sufficient amount of years, as the early stages of a business are defined by less than three and a half years in existence (DTI 2008).

In Table 2, the reliability of five factors through Cronbach's alpha coefficient is depicted. Items $\geq 0.4$ were considered (Stevens 2002), and reliability coefficients with a value $\geq 0.6$ were regarded as sufficient (Malhotra 2010).

In terms of the types of motivation to start the business by the respondents, 'People' $(\alpha=0.81)$, 'Education' $(\alpha=0.71)$ and 'Employment experience' $(\alpha=0.60)$ displayed satisfactory reliability coefficients. With regard to how well the respondents managed with business skills, 'Financial and marketing skills' $(\alpha=0.84)$ and 'Business plan development skills' ( $\alpha=0.84)$ displayed good reliability coefficients. Items that did not yield reliable factors are reported in Table 3 as individual items.

Practically significant differences in means between demographical data and respondents' current uses,
TABLE 3: Individual items in relation to associations between variables. Questions extracted from questionnaire

- What is your highest level of education that you passed? Cramer's $V$

- Do you save some of the money after your expenses have been paid?

- What is your gender?

- Do you have a business plan for your business?

- What is your gender?

- How well do you understand what a business plan is?

- What is your age?

- When calculating the price of a product, do you consider equipment (machines, over lockers, irons, fusing press, etc.)

- How long have you been in business for?

- Do you try to have the lowest prices?

- Which type of ownership is your business?

- Do you try to have the lowest prices?

- How long have you been in business for?

- When calculating the price of a product, do you consider

profit?

- How long have you been in business for?

- Do you charge extra for changing the size of a pattern?

- How long have you been in business for?

- Do you charge extra when a client changes their mind during or after the production stage?

- How did you get your business?

- When calculating the price of a product, do you consider telephone/cell phone expenses (airtime)?

- How did you get your business?

- When calculating the price of a product, do you consider insurance on equipment?

Which type of ownership is your business?

- When calculating the price of a product, do you consider rent of your house/work area?

- Which type of ownership is your business?

- When calculating the price of a product, do you consider water and electricity?

- Where do you operate your business from?

- When calculating the price of a product, do you consider rent of your house/work area?

- Where do you operate your business from?

- When calculating the price of a product, do you consider water and electricity?

- How many employees do you have?

- When calculating the price of a product, do you consider salaries/wages of employees?

- How many employees do you have?

- Do you have an invoice booklet?

- How many employees do you have?

- Do you keep a record of the money in your business?

- Which type of ownership is your business?

- Do you keep a record of the money in your business?

- How many employees do you have?

- Do you use a computer to help you with bookkeeping?

- How many employees do you have?

- Do you have a bookkeeper?

- Which type of ownership is your business?

- Do you have a bookkeeper?

- How many employees do you have? - Do you market your business via advertisements in the
newspaper?

- How many employees do you have?

- Do you market your business via pamphlets?

- How many employees do you have?

- Do you market your business via fashion shows?

- How long have you been in business for?

- How important do you think it is to have training in business skills?

- How did you get your business?

- How important do you think it is to have training in business skills?

challenges and training needs were determined with ANOVAs and T-tests. Spearman's correlation coefficients were used to determine correlations between nominal and ordinal variables for sections of the questionnaire and crosstabulations present associations between two or more variables, described simultaneously (Malhotra 2015). Low effect sizes are not reported. 


\section{Education and saving money}

The association between respondents' highest level of education and saving money after paying expenses is reported. The fashion entrepreneur needs to possess basic numeracy skills to determine how much money to save and how much to re-invest into the business (Groenewald 2001). The respondents who completed a Grade 8 level of education (3.8\%) did not save money after paying their business expenses. However, the respondents with higher levels of education (Grade 9 to Grade 12) reported to saving money after paying their expenses (Cramer's $V=0.42$ ). Based on this result, it may be inferred that the majority of respondents possess basic numeracy skills. Literature indicates that higher numeracy skills are known to strengthen entrepreneurial skills (Gibb 2007:5).

\section{Gender, business plan development, financial and marketing skills challenges}

The differences between gender and challenges with 'Financial and marketing skills' and 'Business plan development skills' are discussed. Male respondents experienced less challenges than female respondents with 'Financial and marketing skills' (mean $=2.65 ; \pm \mathrm{SD}=0.33 ; d=0.57$ ) and 'Business plan development skills' (mean $=2.40 ; \pm \mathrm{SD}=0.68$; $d=0.71$ ) as the skills were rated between average and good. It may therefore be interpreted that male fashion entrepreneurs possess stronger business skills than female fashion entrepreneurs. Unemployment rates tend to be larger amongst females than in males by 2.7\% (Stats SA 2020), especially amongst black women with below Grade 12 qualification (Ramukumba 2014:22), indicating that men may have more likely been employed and acquired business skills instead of women. Female fashion entrepreneurs constitute the majority of the sample population and are less likely to be empowered, operating less successful fashion businesses than male fashion entrepreneurs. It may therefore be suggested that black female fashion entrepreneurs require business skills training, to successfully operate and sustain their fashion businesses within peri-urban communities.

\section{Gender and business plan development skills}

In terms of the correlation between gender and business plan development skills, the majority of the respondents did not have a business plan for their business $(76 \%)$, which was more prominent amongst female respondents $(80 \%)$ as opposed to male respondents $(53.8 \%)$ who did have a business plan (Cramer's $V=0.30)$. Female respondents also reported a poor understanding of the business plan (33.3\%), compared to the majority of male respondents $(75 \%)$ who understood it well (Cramer's $V=0.31$ ). These results are noteworthy as the majority of respondents in the study were female $(84.5 \%)$, indicating poor usage and understanding of business plans amongst fashion entrepreneurs without formal fashion-related education or training in the ELM.

As the business plan is a key document (describing every aspect of the business, where it plans to go and how it plans to get there), it should be developed and implemented in order for the growth of the fashion business to take place (Burke 2010; eds. Erasmus et al. 2013; Garavan \& O'Cinneide 1994:6; Groenewald 2001). It would therefore be beneficial to target and train female fashion entrepreneurs with a focus on improving their understanding and development of a business plan to contribute towards empowerment and sustaining of their fashion businesses.

\section{Age and considering equipment when calculating the selling price}

The association between the respondents' age and including equipment to calculate the selling price of fashion-related products is reported. Equipment is considered an expense in the business because of its depreciation in value. Therefore, it should be considered when calculating the selling price. From all of the age groups, the majority of respondents between 18 and 59 years (mean score ranging from 52\% to $69.9 \%$ ) tend to consider equipment (such as sewing machines) as an expense when calculating the selling price of fashion products. The oldest age group (60 years and older) reported that they did not consider equipment in their selling price (76.9\%; Cramer's $V=0.30)$. It may be likely that older generations do not perform accurate cost-calculations, thereby estimating the selling price of their products. The price at which the fashion entrepreneur sells their product needs to cover the cost of producing the garment, overhead expenses and profit (Meadows 2012). As overhead expenses include the equipment in the business, it should be considered (Meadows 2012).

\section{Years in business, business ownership and lowest pricing}

The association between the number of years the respondents have been in business and trying to have the lowest prices for their fashion-related products and services, along with the business' form of ownership and trying to have the lowest prices for products and services, are reported. The respondents who have been in business for 2, 3 and 5 years (57.1\%, $83.3 \%$ and $78.9 \%$, respectively) aimed to have the lowest prices for their products and services. It was not considered important for businesses that had been in operation for 4 years (as only 33.3\% of these respondents indicated that they aimed to have the lowest prices; Cramer's $V=0.30)$.

Furthermore, regardless of the business' form of ownership (either sole-proprietorship or partnership), the respondents tried to have the lowest prices in their business (Cramer's $V=$ 0.30 ) in order to survive and remain competitive. Small business regulations increase the business' operating costs and cause a barrier for the micro business to survive and remain competitive (National Treasury 2016), resulting in the respondents lowering their prices in order to retain and gain more clients. However, Malgas and Zondi (2020:8) suggest competitive pricing strategies to be the key in sustaining and growing small businesses. A need for training is therefore identified on determining correct product pricing for operating a sustainable fashion business. 


\section{Years in business and profit}

The association between the number of years the respondents have been in business and including profit to calculate the selling price for fashion-related products is reported. From the $87.6 \%$ of respondents who reported to consider profit when calculating the selling price of their products, the respondents who have been in business for 2 years and more also reported to consider their profit (mean $=82.9 \%$; Cramer's $V=0.30$ ). As profit is only achieved when the selling price exceeds the costs involved (eds. Erasmus et al. 2013), it may be interpreted that the respondents are aware of selling their fashion-related products for more than it cost to produce them. However, this remains questionable because of the poor success reported for the survivalist fashion business (59\%).

\section{Years in business and extra charges}

The association between the number of years the respondents have been in business and whether they charge extra for pattern alteration and when clients change their mind during or after the production stage, are reported. The respondents who had been in operation for 4 years and more tended to charge extra to alter the size of a pattern (50\% and 56.6\%, respectively) as opposed to businesses that had been in operation for less than 4 years $(93.3 \%$ and $66.7 \%$; Cramer's $V=0.36)$. Similarly, the respondents who were in operation for 4 years and more $(66.7 \%$ and $60.5 \%)$, charged clients extra for changing their mind about the garment initially ordered, once production had begun, compared to the respondents who were still in the early stages of operating their business ( $80 \%$ and $60 \%$, respectively; Cramer's $V=0.30$ ). It may be interpreted that the respondents who have been operating their business for longer have more business skills and experience (Stafford et al. 2010) and will thereby charge extra for pattern alterations and/or when clients change their minds during or after the production stage.

\section{Business acquisition and selling price}

The association between how the business was acquired and whether the respondents included telephone or cell phone expenses and insurance to calculate their selling price are reported. From the majority of respondents who established their own business (89.4\%), 64.5\% did not consider their telephone and cell phone expenses when calculating the selling price for fashion-related products. The respondents who had acquired their business through other forms (namely bought the business, bought into the business or inherited the business), included telephone and cell phone expenses (81.8\%; Cramer's $V=0.30)$. Similarly, from the majority of respondents who did not include insurance when calculating their selling price $(84.6 \%)$, it was predominant amongst respondents who had established their own business (89.1\%; Cramer's $V=0.37)$.

As overhead expenses when calculating the selling price include telephone expenses or airtime and insurance (Meadows 2012), these expenses should be included.
However, because of the majority of respondents establishing their own business from home (79.6\%), the respondents may not consider such expenses, as they are not separate from the home expenses. The respondents may also not consider the importance of having insurance because of the comfort of working within the home environment and the additional expense of insurance.

\section{Business ownership, business location and selling price}

Considering business ownership, location and selling price, the following associations are reported: the business' form of ownership and whether respondents include rent and water and electricity to calculate their selling price, and the business' location and whether rent and water and electricity are included. The respondents who were the sole proprietors of their business did not consider the rent of their house or work area when calculating the selling price of their products $(73.7 \%)$, whereas the respondents with partners in the business tended to consider rent (58.6\%; Cramer's $V=0.30)$. Similarly, the respondents who were the sole proprietors of their business did not consider the cost of water and electricity $(59.2 \%)$, whereas those with partners in the business did consider their water and electricity $(71.4 \%$; Cramer's $V=0.30)$.

The results further indicated that the respondents who operated their business from home also did not consider the rent of their house when calculating the selling price of a product $(78 \%)$, as opposed to the respondents who had their business next door and away from home (Cramer's $V=0.55)$. Additionally, the respondents operating their business from home did not consider water and electricity for their house or work area (58\%), compared to those who had their business next door and away from home (Cramer's $V=0.34$ ).

It may be interpreted that because a partner contributes their experience, expertise, skills, capital, resources, time and interest into the business (Burke 2010; Cloete \& Marimuthu 2011; Groenewald 2001), it would be more likely for the fashion partnership to rent a work space from which to operate the business for a professional work address and a separation between a work and personal life (Meadows 2012). A partner may further influence the inclusion of rent and water and electricity under indirect costs (Meadows 2012) as expenses of the business are often divided equally between partners (Burke 2010; Juul 2002; Meadows 2012).

\section{Employees and salaries and wages}

The association between the number of employees in the business and whether the respondents include employees' salaries and wages to calculate their selling price is reported. The respondents with one employee tend not to include employees' salaries and wages when calculating the selling price for fashion-related products $(62.9 \%)$, as opposed to the respondents with more employees (mean scores ranging from $72.7 \%$ to $100 \%$ for two to five employees; Cramer's $V=0.45)$. More employees in the business result in additional 
expenses. Therefore, the respondents will consider their employees' salaries and wages when calculating the selling price, in order to cover their expenses. However, businesses in resource-poor areas, such as the ELM, tend to have less employees; as such, these businesses have a low average payroll (Kugler et al. 2017:iv).

\section{Employees and invoice booklets}

The association between the number of employees in the business and whether respondents had an invoice booklet is discussed. The respondents operating with one employee $(68.3 \%)$ were less likely than businesses with two to five employees (mean scores ranging from $58.3 \%$ to $100 \%$ ) to have invoice booklets (Cramer's $V=0.38$ ). It may be inferred that the more employees the business has, the more diverse the set of skills are and the more likely the business is to issue invoices to clients. Therefore, businesses with only one employee may lack the skill to draft an invoice for clients, highlighting a need for training on drafting invoices within the daily operations of the fashion business. According to Ponelis and Britz (2011:15), South African small and medium enterprises need to provide more detail on their invoices, as a lack of information is used as an excuse for delayed payments, affecting the business' cash flow.

\section{Employees, business ownership and record keeping}

The association between the number of employees in the business and keeping a record of money versus the business' form of ownership and keeping a record of money are reported. In terms of the number of employees per business, for respondents with one employee, more than half of the respondents tended not to keep a record of the money in their business (54\%). The respondents who did keep a record of their money, generally had between two and five employees (mean scores ranging from $66.7 \%$ and $100 \%$; Cramer's $V=0.33$ ). It may be inferred that the respondents with more employees were better at record keeping.

In addition, half of the respondents (50\%) who were sole proprietors also kept a record of their money, along with respondents who were in a partnership (79.3\%; Cramer's $V=0.30$ ). It is important for sole proprietorships and partnerships to keep a record of all its income and expenses for tax purposes (Meadows 2012), and it is suggested that by regularly monitoring the financial records of the business, financial trends, strengths and weaknesses become evident (eds. Erasmus et al. 2013).

\section{Employees, business ownership and bookkeeping}

The following section reports the association between the number of employees in the business, whether respondents used a computer to assist them with bookkeeping, or had a bookkeeper. The association between the business' form of ownership and having a bookkeeper is also reported.
The respondents with one to three employees were less likely to use a computer for bookkeeping, as opposed to respondents with four and five employees who were more likely to do so (50\% and $66.7 \%$, respectively; Cramer's $V=0.38$ ). Similarly, the respondents with one to three employees were more likely not to have a bookkeeper, as opposed to respondents with four and five employees who tended to have a bookkeeper for their business $(50 \%$ and $66.7 \%$, respectively; Cramer's $V=0.44)$. It was further indicated that the respondents who were sole proprietors did not have a bookkeeper $(88.2 \%)$, compared to the respondents with partners who tended to have a bookkeeper (51.7\%; Cramer's $V=0.43)$.

These results are verified by Viswanathan et al. (2009:571) who suggest that entrepreneurs within resource-poor areas (such as those surrounding the ELM) have been found to lack basic financial and accounting skills required to manage their business. Having more employees in the business may result in larger businesses, thus, allowing for a diverse set of skills (such as using a computer to conduct the business' bookkeeping). A partner is also known to bring additional knowledge and capital into the business (Burke 2010; Cloete \& Marimuthu 2011). It may be further interpreted that larger fashion businesses (implicating more employees) would be more likely to afford a computer or a bookkeeper to ensure accurate bookkeeping practices. This highlights a need for fashion entrepreneurs without formal fashion-related education or training, in peri-urban communities, to be equipped with skills in conducting basic bookkeeping, to successfully understand and operate the finances within the fashion business.

\section{Employees and marketing}

The association between the number of employees in the business and respondents' marketing efforts via advertisements in the newspaper, pamphlets and fashion shows is reported. The majority of respondents reported that they did not market their business through newspaper advertisements, regardless of the amount of employees in the business (mean scores ranging from $83.3 \%$ to $100 \%$; Cramer's $V=0.41$ ). In addition, it was indicated that the respondents did not market their business through pamphlets (mean scores ranging from $66.7 \%$ to $100 \%$; Cramer's $V=0.42$ ). As fashion promotion includes the traditional marketing tools of advertising (eds. Erasmus et al. 2013; Groenewald 2001; Jackson \& Shaw 2009), such as newspaper advertising and pamphlets, it may be likely that the respondents are unaware of the advertising avenues available to them. As this study was conducted within the peri-urban, resource-poor communities of the ELM, where Sesotho is the most widely spoken language (Hunter 2016), it may be interpreted that poor fluency in English and the expense of marketing via newspaper advertising and printing of pamphlets, cause barriers to successfully market the fashion business. This indicates a need for training fashion entrepreneurs without formal fashion-related education or training, on cost-effective forms of marketing their fashion business, suitable to their identified target markets. 
Furthermore, the respondents with one to four employees did not market their business through fashion shows; however, respondents with five employees did (66.7\%; Cramer's $V=0.46)$. Although fashion shows showcase and promote the fashion business to current and potential consumers (Jackson \& Shaw 2009; Meadows 2012), it will incur further costs for the business, may be time consuming and requires additional assistance (such as for fashion models and stage productions), thereby, making it a feasible option to larger fashion businesses who have more employees.

\section{Years in business, business acquisition and business skills}

The importance of training in business skills as indicated by the respondents is reported. On average, $90.2 \%$ of respondents who have been operating their business between 2 and 5 years, tended to regard training in business skills as very important (Cramer's $V=0.37$ ). Regardless of how the respondents obtained their business, the majority of respondents regarded training in business skills as very important (82\%; Cramer's $V=0.51)$. This holds true as training and knowledge in business skills are essential to achieve optimal results within the business (Nieuwenhuizen 2008). Whilst business skills were found lacking in past research amongst fashion entrepreneurs in the ELM (Naidoo 2009; Van Wyk \& Van Aardt 2011:182), the above results indicate that the respondents interpret training in business skills as a necessity.

Interpreted results indicated that the respondents lacked skills in business plan development and possessed only moderate skills in finance and marketing. The respondents regarded training in business skills to be very important. The specific training needs derived from the results, as indicated by respondents, include developing a business plan for their business (94.3\%), developing a budget for their business $(90.5 \%)$, conducting market research to determine which fashion-related products and service customers require (96.2\%), basic bookkeeping (89.5\%), advertising products and services (94.3\%), finding the correct price for their products and services (92.4\%) and drafting a quotation for customers $(94.3 \%)$. This is in line with the provision of business skills training for fashion entrepreneurs, as previously suggested by Naidoo (2009:157). Such training should include short business courses that cover business plan development (which will assist fashion entrepreneurs to set up the business, secure finances and determine the long-term viability and success of the business), bookkeeping and marketing (Naidoo 2009:157).

An absolute $100 \%$ of respondents reported that training in business skills could benefit themselves and other fashion entrepreneurs. The most commonly selected language for training to be received was English (50.5\%), followed by Sotho (32\%), Zulu (9.7\%) and Xhosa (7.8\%).

\section{Discussion Key findings and discussion}

Because of the explorative nature of the study, the outcome of the study makes suggestions for business skills training programmes for adult fashion entrepreneurs, without formal fashion-related education or training within peri-urban communities of the ELM. These suggestions are made according to the specific needs identified from the study, through the respondents' own perception of their business skills, presented as a list of priorities. Future interventions, by government or private training institutions, schools and higher education institutions, should therefore be designed as per the following considerations:

- Training needs in eight specific areas, in terms of business plan development skills, financial skills and marketing skills. These findings are supported by literature from Naidoo (2009) and Van Wyk and Van Aardt (2007) and include:

- developing a business plan for a fashion business

- conducting basic bookkeeping

- determining correct product pricing

- drafting quotations

- drafting invoices

- developing a budget

- determining target market needs, and

- advertising the business' products and services.

- Preferred languages to receive fashion business skills training in are English and Sotho.

- Although English was selected by the majority of respondents to receive training in, literature suggests Sesotho is the most widely spoken language within periurban, resource-poor communities of the ELM (Hunter 2016). It could, therefore, be beneficial to have language translators present (with sound fashion knowledge) to further assist participants during English training sessions.

- Word usage during the fashion business skills training should be simplified to colloquial language for a better understanding of concepts for the low-literate fashion entrepreneur, as the majority of adult South Africans experience low literacy levels (Aitchison 2015:134; Posel 2011:39).

- Content of the fashion business skills training should relate directly to the informal, survivalist fashion business, assisting participants in the successful daily operation of their fashion businesses, because of the majority of adult fashion entrepreneurs without formal fashion-related education or training operating within such a business environment (Department of Trade and Industry 2008; eds. Erasmus et al. 2013; Rogerson 2006:69; Small Enterprise Development Agency 2019).

- Fashion business skills training should be offered in small groups of participants, as it may be beneficial for participants to receive specialised, focused attention. A need for training in financial costing exists amongst adult fashion entrepreneurs without formal fashion-related education or training. Literature suggests that entrepreneurs 
within resource-poor areas lack basic financial and accounting skills required to manage various costs in the business and tend to seek advice from neighbours and surrounding locals, thereby having unstable pricing structures (Viswanathan et al. 2009:571).

- As literature suggests word-of-mouth advertising to be the most popular amongst fashion entrepreneurs in the SDM (Naidoo 2009), training programmes should also explore the benefits of alternative, cost effective forms of marketing to promote the fashion business and increase consumer satisfaction.

- Literature suggests that the majority of female fashion entrepreneurs in the SDM were married (Naidoo 2009:129). Thus, there should be a strong focus on business plan development, catered specifically to black, married, female fashion entrepreneurs. This shall lead to empowerment of these fashion entrepreneurs to operate sustainable fashion businesses.

\section{Limitations}

There are limitations for this study because of its nonprobability sampling method (which were used to include respondents within the ELM). Therefore, the results could not be generalised towards the entire population of adult fashion entrepreneurs without formal fashion-related education or training. In addition, two of the larger fabric and haberdashery stores in the ELM denied permission for data to be collected from there, resulting in limited data collection locations and consequently limited access to possible study participants. The respondents were not asked how they measure the success of their business, nor were the success and failure factors of their fashion businesses investigated. The results were self-reported by the respondents, resulting in the subjectivity of responses.

\section{Conclusion}

Given the results of the study, the following conclusions can be made: the respondents are unlikely to have a business plan in place as they reported to struggle the most with business plan development. The respondents also rated their business' success as poor, thereby questioning their skill in finance and marketing. Enthusiasm towards receiving training in business skills was noted by the respondents as they believe it will be beneficial to them and other fashion entrepreneurs. Suggestions were thus developed for possible fashion business skills training programmes.

\section{Recommendations}

The following recommendations are made for future research:

- As responses were self-reported, therefore, unverified, fashion entrepreneurs without formal fashion-related education or training's current use of and challenges with financial skills within the survivalist fashion business may warrant further investigation.

- There is a need to determine the motivation for adult fashion entrepreneurs without formal fashion-related education or training starting their own business, as this aspect remains unclear.

- The measures of business success and failure according to fashion entrepreneurs without formal fashion-related education or training need to be determined.

- Alternatives to training programmes, the development of translated fashion business skills booklets could be considered to assist fashion entrepreneurs without formal fashion-related education or training in the daily operation of their business (e.g. costing sheet templates available in Sotho).

Whilst this study determined the business skills training needs for adult fashion entrepreneurs without formal fashion-related education or training (in terms of business plan development skills, financial skills and marketing skills), other training needs related to fashion entrepreneurial skills may remain. These training needs may include practical items such as sewing skills, pattern drafting skills, visual communication skills and skills related to literacy and numeracy (mathematics).

\section{Acknowledgements}

This manuscript (61\%) stems from a published thesis submitted 2019 in fulfilment of the requirements for the degree of Magister Technologiae in Fashion in the Vaal University of Technology, Vanderbijlpark, entitled: 'Uses, challenges and training needs regarding business skills for fashion entrepreneurs in the Emfuleni local municipality' by Keshni Nana. Available here: http:/ /digiresearch.vut.ac.za/ xmlui/bitstream/handle/10352.

\section{Competing interests}

The authors declare that they have no financial or personal relationships that may have inappropriately influenced them in writing this article.

\section{Authors' contributions}

K.N. conceptualised the research study that was part of her MTech dissertation. H.v.S. and N.C. were the supervisors who assisted with the conceptualisation of the study and approved the article to be published.

\section{Funding information}

The financial assistance of the National Research Foundation (NRF) towards this research is hereby acknowledged. Opinions expressed and conclusions arrived at are those of the author and are not necessarily to be attributed to the NRF.

\section{Data availability}

Data sharing is applicable to this article as new data were created and analysed. Data may be obtained from the corresponding author, K.N., upon reasonable request. 


\section{Disclaimer}

The views expressed in this article are those of the authors and do not reflect the official position of any affiliated agency of the authors.

\section{References}

Aitchison, J., 2015, 'Proxies and perplexities: What is the current state of adult (il) literacy in South Africa?', Journal of Education 66, 111-138.

Babbie, E.R., 2010, The practice of social research, 12th edn., Wadsworth Cengage Learning, Belmont.

Babbie, E.R., 2013, The practice of social research, 13th edn., Wadsworth Cengage Learning, Belmont.

Babbie, E.R. \& Mouton, J., 2016, The practice of social research, Oxford University Press, Cape Town.

Breward, C., 2010, 'Avis Charles: Aspects of a conversation', Journal of Dress, Body and Culture 14(3), 355-360. https://doi.org/10.2752/175174110X12712411520296

Bureau for Economic Research, 2016, The small, medium and micro enterprise sector of South Africa, Research note no.1, January 2016, Stellenbosch University, Stellenbosch

Burke, S., 2010, Fashion entrepreneur: Starting your own fashion business, Burke Publishing, London.

Cloete, M. \& Marimuthu, F., 2011, Basic accounting for non-accountants, Van Schaik Publishers, Pretoria.

Coleman, S., 2000, 'Access to capital and terms of credit: A comparison of men- and women- owned small businesses', Journal of Small Business Management 38(3), 37-52.

Creswell, J.W., 2014, Research design: Qualitative, quantitative, and mixed method approaches, 4th edn., Sage Publications, London.

Daniel, J., 2012, Sampling essentials: Practical guidelines for making sampling choices, Sage Publications, Los Angeles, CA.

Department of Cooperative Governance and Traditional Affairs, 2020, Sedibeng district municipality, viewed 05 February 2021, from https://www.cogta.gov.za/ $\mathrm{ddm} /$ wp-content/uploads/2020/07/District_Profile_SEDIBENG-1.pdf.

Department of Trade and Industry, 2008, Annual review of small businesses in South Africa 2005-2007, The Department of Trade and Industry, Pretoria.

Erasmus, B.J., Strydom, J.W. \& Rudansky-Kloppers, S. (eds.), 2013, Introduction to business management, 9th edn., Oxford University Press, Cape Town.

Fernandes, C.E., 2019, 'Fashion design entrepreneurship: Skills and solutions to create a fashion business', Journal of Textile Science \& Fashion Technology, 3(1), 1-3. https://doi.org/10.33552/JTSFT.2019.03.000553

Garavan, T.N. \& O'Cinneide, B., 1994, 'Entrepreneurship education and training programmes: A review and evaluation - Part 1', Journal of European Industrial
Training 18(8), 3-12. https://doi.org/10.1108/03090599410068024

Gauteng Provincial Treasury, 2019, Socio-economic review and outlook, viewed 05 February 2021, from http://www.treasury.gov.za/documents/provincial\%20 bebruary 2021, from http://www.treasury.gov.za/documents/provincial $\% 20$ GT/1.\%20Budget $\% 20$ Overview/GT\%20-020EPRE $\% 20$ - $\% 20$ Budget $\% 20$ $\mathrm{GT} / 1 . \% 20 \mathrm{Bud}$
Overview.pdf

Gibb, A., 2007, 'Enterprise in education: Educating tomorrow's entrepreneurs', Paper presented as part of the course in Small Business Management, Durham presented as part
University, Durham.

Google Maps, 2020, Distance from Johannesburg to Sedibeng, viewed 25 November 2020, from https://www.google.com/maps/dir/johannesburg/ sedibeng+district+municipality/@-26.443438,27.9223798,10z/data=!3m1!4b sedibeng+district+municipality/@-26.48f438,27.9223798,10z/data=!3m1!4b ! $1 \mathrm{~d} 28.0473051$ ! $2 \mathrm{~d}-26.2041028$ ! $1 \mathrm{~m} 5$ ! $1 \mathrm{~m} 1$ 1! $1 \mathrm{~s} 0 \times 1 \mathrm{e} 94 \mathrm{e} 65788245 \mathrm{ed} 9: 0 \times 840 \mathrm{e} 7 \mathrm{c}$ !1d28.0473051!2d-26.2041028! $1 \mathrm{~m} 5$ ! $1 \mathrm{~m} 1$ ! $1 \mathrm{~s} 0 \times 1 \mathrm{e}$

Gorard, S., 2013, Research design: Creating robust approaches for the social sciences, Sage Publications, London.

Groenewald, J., 2001, Mind your own design business, 2nd edn., Flexfin, Cape Town.

Hunter, D., 2016, Sedibeng, viewed 23 April 2016, from http://www.davishunter.com/ home/place/Sedibeng.

Isaacs, E., Visser, K., Friedrich, C. \& Brijlal, P., 2007, 'Entrepreneurship education and training at the Further Education and Training (FET) level in South Africa', South African Journal of Education 27(4), 613-629.

Jackson, T. \& Shaw, D., 2009, Mastering fashion marketing, Palgrave Macmillan, Hampshire.

Juul, I., 2002, The small business survival handbook, New Africa Books, Cape Town.

Kamara, Y., 2014, Challenges for African women entrepreneurs in the performing arts and designer fashion sectors, viewed 14 November 2018, from https://www. researchgate.net/publication/271515276_Challenges_for_African_women entrepreneurs in the performing_arts_and_designer_fashion_sectors.

Kugler, M., Michaelides, M., Nanda, N. \& Agbayani, C., 2017, 'Entrepreneurship in low income areas', Office of Advocacy U.S. Small Business Administration unde contract number SBAHQ-15-M-0150, pp. 1-49.

Kunene, T., 2008, 'The training of entrepreneurs and small business owners in the textile and clothing industry in the Gauteng province', PhD thesis, University of Pretoria.
Ladzani, W.M. \& Van Vuuren, J.J., 2002, 'Entrepreneurship training for emerging SMEs in South Africa', Journal of Small Business Management 40(2), 154-161. https:// doi.org/10.1111/1540-627X.00047

Lewis, C. \& Gasealahwe, B., 2017, 'Lowering barriers to entrepreneurship and promoting small business growth in South Africa', OECD Economics Department Working Papers No. 1449. https://doi.org/10.1787/18151973.

Ligthelm, A.A., 2008, 'A targeted approach to informal business development: the entrepreneurial route', Development Southern Africa 25(4), 367-382. https://doi. org/10.1080/03768350802316138

Malgas, M. \& Zondi, W.B., 2020, 'Challenges facing small business retailers in selected South African townships', Southern African Journal of Entrepreneurship and Small Business Management 12(1), a2020. https://doi.org/10.4102/sajesbm.v12i1.202

Malhotra, N.K., 2010, Marketing research: An applied orientation, 6th edn., Pearson Education, Upper Saddle River, NJ.

Malhotra, N.K., 2015, Essentials of marketing research: A hands on orientation, Pearson Education, London.

Maree, K. (ed.), 2007, First steps in research, Van Schaik Publishers, Pretoria.

Martins, J.H., 2005, 'Interviewer-administrated primary data collection', in T.A. Tustin A. Ligthelm, J.H. Martins \& H.D.J. Van Wyk (eds.), Marketing research in practice, pp. 141-183, Unisa Press, Epping.

Mavunga, G. \& Cross, M., 2017, 'The culture of employee learning in South Africa: Towards a conceptual framework', Journal of Education 2017(69), 303-326.

Mayombe, C., 2017, 'Non-formal adult education for self-employment: The importance of post-training support for micro-enterprise development in South Africa', Journal of Education 67, 149-178.

Meadows, T., 2012, How to set up and run a fashion label, 2nd edn., Laurence King Publishing, London.

Moloi, K.C. \& Nkhahle, M.A., 2014, 'Perceived success of entrepreneurs in the Vaal region of South Africa with special reference to fashion entrepreneurs', Mediterranean Journal of Social Sciences 5(1), 225-233. https://doi.org/10.5901/ mjss.2014.v5n1p225

Naidoo, R.M., 2009, 'The job demands and job resources associated with female fashion entrepreneurs of small fashion businesses in the Vaal region', MTech dissertation, Vaal University of Technology.

Nardi, P.M., 2006, Doing survey research: A guide to quantitative methods, 2nd edn., Pearson Education, Boston, MA.

National Treasury, 2016, Budget review, National Treasury Republic of South Africa, Pretoria.

Nheta, D.S., Shambare, R., Sigauke, C. \& Tshipala, N., 2020, 'Entrepreneurship gaps framework model: An early-stage business diagnostic tool', Southern African framework model: An early-stage business diagnostic tool', Southern African Journal of Entrepreneurship and Small
doi.org/10.4102/sajesbm.v12i1.297

Nieuwenhuizen, C. (ed.), 2008, Entrepreneurial skills, 2nd edn., Juta, Cape Town.

Oishi, S.M., 2003, How to conduct in-person interviews for surveys, 2nd edn., Sage Publications, Los Angeles, CA.

Pallant, J., 2010, SPSS survival manual: A step by step guide to data analysis using the SPSS program, 4th edn., McGraw Hill, Maidenhead.

Palys, T., 2008, 'Purposive sampling', in L.M. Given (ed.), The Sage encyclopaedia of qualitative research methods, pp. 697-698, Sage Publications, Los Angeles, CA.

Ponelis, S.R. \& Britz, J.J., 2011, 'An exploratory study of business intelligence in knowledge-based South African SMEs', viewed 15 February 2021, from http:// citeseerx.ist.psu.edu/viewdoc/download?doi=10.1.1.688.4642\&rep=rep1\&type= pdf.

Posel, D., 2011, 'Adult literacy rates in South Africa: A comparison of different measures', Language Matters 42(1), 39-49. https://doi.org/10.1080/10228195.2 011.571703

Ramukumba, T., 2014, 'Overcoming SMEs challenges through critical success factors: A case of SMEs in the Western Cape Province, South Africa', Economic and Business Review 16(1), 19-38. https://doi.org/10.15458/2335-4216.1178

Redmond, J. \& Walker, E.A., 2008, 'A new approach to small business training: Community based education', Education and Training 50(8/9), 697-712. https:// doi.org/10.1108/00400910810917073

Rogerson, C.M., 2000, 'Successful SMEs in South Arica: The case of clothing producers in the Witwatersrand', Development Southern Africa 17(5), 687-712. https://doi. org/10.1080/713661433

Rogerson, C.M., 2006, 'Developing SMMEs in peripheral spaces: The experience of Free State Province, South Africa', South African Geographical Journal 88(1), 6678. https://doi.org/10.1080/03736245.2006.9713848

Rogerson, C.M., 2008, 'Tracking SMME development in South Africa: Issues of finance, training and the regulatory environment', Urban Forum 19(1), 61-81. https://doi. org/10.1007/s12132-008-9025-x

Rwigema, H. \& Venter, R., 2007, Advanced entrepreneurship, Oxford University Press, Cape Town.

Small Enterprise Development Agency, 2019, SMME quarterly update: 1st quarter 2019, viewed 09 February 2021, from http://www.seda.org.za/Publications/ Publications/SMME\%20Quarterly\%202019-Q1.pdf.

Stafford, K., Bhargava, V., Danes, S.M., Haynes, G. \& Brewton, K.E., 2010, 'Factors associated with long-term survival of family businesses: Duration analysis', Journal of Family and Economic Issues 31(4), 442-457. https://doi.org/10.1007/s10834 010-9232-1

Statistics South Africa, 2020, Statistical release: Quarterly labour force survey: Quarter 3: 2020, Statistics South Africa Republic of South Africa, Pretoria. 
Statistics South Africa, 2021, Media release: Quarterly labour force survey (QLFS) Q1:2021, Pretoria.

Stevens, J.P., 2002, Applied multivariate statistics for the social sciences, 4th edn., Erlbaum, Mahwah, NJ.

Vaal University of Technology, 2020, Diploma: Fashion, viewed 25 November 2020, from https://www.vut.ac.za/wp-content/uploads/2020/10/Courses-and-programmes. FHS_.pdf.

Van Wyk, A.W., 2007, 'Small fashion business owners and their businesses in the Vaal region', MTech dissertation, Vaal University of Technology.
Van Wyk, A.W. \& Van Aardt, A.M., 2011, 'Attributes, skills and knowledge of fashion entrepreneurs: An integrated perspective', Journal for New Generation Sciences 9(1), 165-188.

Viswanathan, M., Gau, R. \& Chaturvedi, A., 2008, 'Research methods for subsistence marketplaces', in P. Kandachar \& M. Halme (eds.), Sustainability challenged and solutions at the base of the pyramid, pp. 242-260, Greenleaf, Sheffield.

Viswanathan, M., Sridharan, S. \& Ritchie, R., 2009, 'Understanding consumption and entrepreneurship in subsistence marketplaces', Journal of Business Research 63(6), 570-581. https://doi.org/10.1016/j.jbusres.2009.02.023 